\title{
Mast cell infiltration around gastric cancer cells correlates with tumor angiogenesis and metastasis
}

\author{
Hiroshi Yano ${ }^{1}$, Masakatsu Kinuta ${ }^{1}$, Hideo Tateishi ${ }^{1}$, Yoshiaki Nakano ${ }^{1}$, Shigeo Matsui ${ }^{1}$, Takushi Monden ${ }^{1}$, \\ Jun OKamura ${ }^{1}$, Masahide Sakai ${ }^{2}$, and Shigeru OKamoto ${ }^{2}$ \\ ${ }^{1}$ Department of Surgery, Osaka Teishin Hospital, 2-6-40 Karasugatsuji, Tennoji-ku, Osaka 543, Japan \\ ${ }^{2}$ Department of Pathology, Osaka Teishin Hospital, Osaka, Japan
}

\begin{abstract}
:
Background. Increased numbers of mast cells are found in various solid tumors. To investigate the role of mast cells in the vicinity of gastric cancer cells, we used special staining and an immunohistochemical technique.

Methods. Specimens were surgically obtained from 102 patients with gastric cancer. Mast cells around the tumor edge of gastric cancer nests were counted by staining with $0.05 \%$ toluidine blue solution. Blood vessels in these areas were also counted, by immunohistochemical staining of endothelial cells for factor VIII.

Results. The average number of mast cells and blood vessels in gastric cancer specimens was significantly higher than that in normal gastric tissue. Specimens from patients with advanced disease with metastases to lymph nodes had more mast cells than specimens from patients with early-stage disease. Mast cells in specimens from patients with metastatic lymph nodes were significantly increased in comparison with numbers in specimens from those without nodal metastases. Mast cell numbers in the specimens of patients with lymphatic or blood vessel invasion were significantly higher than numbers in specimens from patients without such invasion. Mast cells were localized near the new vessels around gastric cancer cells. Mast cell numbers increased as the number of blood vessels increased (correlation coefficient, 0.783). Postoperative survival curves revealed that patients with increased numbers of mast cells had a poor prognosis.

Conclusions. All these results suggest that mast cell accumulation at the tumor site may lead to increased rates of tumor vascularization and, consequently, increased rates of tumor growth and metastasis.
\end{abstract}

Key words: mast cell, factor VIII, gastric cancer, angiogenesis, metastasis

Offprint requests to: $\mathrm{H}$. Yano

Received for publication on Oct. 9, 1998; accepted on Feb. 1, 1999

\section{Introduction}

A variety of studies have demonstrated that an increased number of mast cells is an early and persistent finding in various naturally occurring solid tumors. Baroni [1] reported increased mast cell numbers in several tumors, including neurofibromas, lipomas, and hemangiomas, a result later confirmed by Glowacki and Mulliken [2] and by Ho [3]. Increased numbers of mast cells have also been reported in human adrenocortical tumors [4] and in a variety of skin tumors [5]. In experimental animals, mast cell infiltration and degranulation were observed to be concurrent with the development of epidermoid carcinomas in carcinogen-treated hamsters [6] and were seen at the periphery of tumors implanted onto the chorioallantoic membranes of chick embryos [7]. However, the roles of mast cells around cancer cells are obscure.

New blood vessel formation in the vicinity of cancer cells, or tumor angiogenesis, is a fundamental component of tumorigenesis, tumor growth, and metastasis. Weidner et al. [8] reported a significant correlation between the density of microvessels in histologic sections of invasive breast carcinoma stained for factor VIII and the occurrence of metastases. In a variety of tumors, such as gastric cancer and breast cancer, the vessel density is reported to be a prognostic indicator $[9,10]$. To date, more than a dozen purified molecules have been shown to be angiogenic, such as acidic and basic fibroblast growth factor (aFGF, bFGF), vascular endothelial growth factor (VEGF), epidermal growth factor (EGF), and platelet-derived endothelial cell growth factor (PD-ECGF).

To identify the role of mast cells around gastric cancer cells, we investigated the relationship between numbers of mast cells and microvessels by special staining for mast cells and immunohistochemical staining, using an anti-human factor VIII polyclonal antibody. 
Our preliminary clinicopathological and immunohistochemical characterization suggests that mast cell infiltration around gastric cancer cells correlates with tumor angiogenesis and metastasis.

\section{Subjects and methods}

\section{Patients}

One hundred and two patients with adenocarcinoma of the stomach were included in this study, a group which consisted of 75 men and 27 women whose mean age was 60.3 years (range, 35-87 years). Specimens were obtained from these patients with gastric cancer who underwent distal gastrectomy or total gastrectomy with regional lymph node dissection at the Department of Surgery, at Osaka Teishin Hospital, between 1995 and 1997. The patients did not receive any anticancer therapy before surgery. Normal gastric tissues were also obtained, as well as the gastric tumors.

\section{Mast cell staining}

The specimens were fixed with $10 \%$ neutral buffered formalin, embedded in paraffin, cut in 4- $\mu \mathrm{m}$-thick sections, and stained with $0.05 \%$ toluidine blue solution, pH 4.1 (Muto Pure Chemicals, Tokyo, Japan), for 30 min to detect mast cells [11].

\section{Blood vessel staining}

All blood vessels around the gastric cancer cells of 49 patients were highlighted by staining endothelial cells for factor VIII, by the streptavidin-biotin method [12]. The sections were dewaxed in xylene and taken through ethanol. After the blocking of endogeneous peroxidase activity, the sections were incubated with $3.0 \%$ normal goat serum for $30 \mathrm{~min}$ to prevent nonspecific binding. They were then washed with phosphate-buffered saline (PBS), and incubated with anti-human factor VIII polyclonal antibody (Dako, Tokyo, Japan) at room temperature for $20 \mathrm{~min}$. They were well washed with PBS and incubated with biotinylated anti rabbit $\mathrm{IgG}$ diluted in PBS containing 1.0\% normal goat serum for $30 \mathrm{~min}$. After being washed with PBS, they were incubated with streptavidin-biotin peroxidase reagent for $30 \mathrm{~min}$. Peroxidase staining was performed for $4 \mathrm{~min}$, using a solution of $40 \mathrm{mg}$ 3,3'-diaminobenzidine tetrahydrochloride in $200 \mathrm{ml} 0.05 \mathrm{M} \mathrm{pH} 7.6$ Tris- $\mathrm{HCl}$ buffer containing $40 \mu \mathrm{l}$ of $30 \%$ hydrogen peroxide. The slides were immersed in $0.05 \%$ toluidine blue solution for $30 \mathrm{~min}$ to perform double staining of mast cells and blood vessels.

\section{Histological findings and determination of mast cell and blood vessel numbers}

Mast cells and blood vessels around the tumor edge of gastric cancer nests were counted using a light microscope (number per $100 \times$ field). The average number of mast cells and blood vessels in three fields selected at random was calculated. The tumors were classified pathologically according to the 12th Japanese edition of the General rules for gastric cancer study [13].

\section{Prognosis}

The prognosis of the patients was examined on September 30, 1998. Survival curves for patients were calculated using the Kaplan-Meier method and analyzed by the general Wilcoxon test.

\section{Statistics}

Data values were statistically analyzed by Student's $t$-test. Probability values less than 0.05 were considered significant.

\section{Results}

\section{Mast cell and factor VIII expression}

The granules in mast cell cytoplasm were stained purple by toluidine blue, and the blood vessels were stained brown by anti-factor VIII polyclonal antibody. In normal gastric tissue, mast cells existed diffusely from the submucosa to the muscle layer; the average number was $27 \pm 1$ per field $(\times 100)$ by light microscope (Fig. 1$)$. The average mast cell number $(70 \pm 6)$ in the tumor tissue of 102 patients with gastric cancer was significantly higher than that in normal gastric tissue (Fig. 2). The average number of blood vessels from the submucosa to the muscle layer in normal gastric tissue was $22 \pm 2$. The average number of blood vessels in the tumor tissue of 49 patients with gastric cancer $(54 \pm 5)$ was significantly higher than that in normal gastric tissue (Table 1).

\section{Correlation between clinicopathological factors and mast cell numbers}

Table 2 shows the correlation among clinicopathological factors, mast cell numbers, and blood vessel numbers in the patients with gastric cancer. We analyzed the data according to depth of gastric cancer invasion. The abbreviations used for histology are: tub1, well differentiated tubular adenocarcinoma; tub2, moderately differentiated tubular adenocarcinoma; por1, 
Table 1. Mast cell and blood vessel numbers around normal gastric tissue and gastric cancer

\begin{tabular}{|c|c|c|c|c|c|c|}
\hline & $\begin{array}{r}\text { Number of } \\
\text { (Means }\end{array}$ & $\begin{array}{l}\text { nast cells } \\
+\mathrm{SE})\end{array}$ & & $\begin{array}{r}\text { Number of } \\
\text { (Means }\end{array}$ & $\begin{array}{l}\text { ood vessels } \\
\pm \mathrm{SE})\end{array}$ & \\
\hline & No. of patients & & & No. of patients & & \\
\hline $\begin{array}{l}\text { Normal gastric } \\
\text { tissue }\end{array}$ & 20 & $27 \pm 1 \longrightarrow$ & \multirow{2}{*}{$*$} & 10 & $22 \pm 2$ & \multirow{2}{*}{ J } \\
\hline Gastric cancer & 102 & $70 \pm 6$ & & 49 & $54 \pm 5$ & \\
\hline
\end{tabular}

$* P<0.01$

Table 2. Correlation between clinicopathologic factors and numbers of mast cells and blood vessels around gastric cancer

\begin{tabular}{|c|c|c|c|c|}
\hline \multirow[b]{2}{*}{ Factors } & \multicolumn{2}{|c|}{ Number of mast cells (Means $\pm \mathrm{SE}$ ) } & \multicolumn{2}{|c|}{ Number of blood vessels (Means $\pm \mathrm{SE})$} \\
\hline & No. of patients & & No. of patients & \\
\hline \multicolumn{5}{|c|}{ Histologic type } \\
\hline tub1 & 22 & $41 \pm 4$ & 7 & $37 \pm 8$ \\
\hline sig & 28 & $48 \pm 7$ & 18 & $51 \pm 8$ \\
\hline tub2 & 23 & $89 \pm 19$ & 12 & $55 \pm 13$ \\
\hline por1 & 19 & $98 \pm 15 \longrightarrow *$ & 7 & $63 \pm 10-*$ \\
\hline por2 & 10 & $101 \pm 16$ & 5 & $82 \pm 10 \longrightarrow$ \\
\hline \multicolumn{5}{|c|}{ Depth of invasion } \\
\hline $\mathrm{t} 1$ & 54 & $41 \pm 4$ & 28 & $40 \pm 5 \longrightarrow$ \\
\hline $\mathrm{t} 2$ & 16 & $81 \pm 14$ & 10 & $71 \pm 0-* *$ \\
\hline $\mathrm{t} 3$ & 27 & $104 \pm 15 \square *$ & 10 & $70 \pm 10-$ \\
\hline $\mathrm{t} 4$ & 5 & $163 \pm 51$ & 1 & 151 \\
\hline \multicolumn{5}{|c|}{ Lymph node metastasis } \\
\hline Negative & 70 & $43 \pm 3 \square *$ & 35 & $42 \pm 4 \square *$ \\
\hline Positive & 32 & $130 \pm 14$ & 14 & $88 \pm 87^{*}$ \\
\hline \multicolumn{5}{|c|}{ Lymphatic or vessel invasion } \\
\hline Negative & 69 & $43 \pm 3$ & 34 & $41 \pm 4 \square$ \\
\hline Positive & 33 & $128 \pm 14$ & 15 & $87 \pm 8]^{*}$ \\
\hline \multicolumn{5}{|l|}{ Stage } \\
\hline I & 63 & $43 \pm 3$ & 33 & $43 \pm 5 \square$ \\
\hline II & 15 & $94 \pm 18$ & 7 & $63 \pm 13 *$ \\
\hline III & 10 & $120 \pm 24 \longrightarrow *$ & 3 & $92 \pm 21-*$ \\
\hline IV & 14 & $132 \pm 26$ & 6 & $91 \pm 16$ \\
\hline
\end{tabular}

$* P<0.05$

Tub1, Well differentiated tubular adenocarcinoma; tub2, moderately differentiated tubular adenocarcinoma; por1, poorly differentiated adenocarcinoma solid type; por2, poorly differentiated adenocarcinoma non-solid type; sig, signet-ring cell carcinoma; t1, tumor invades lamina propria or submucosa; $\mathrm{t} 2$, tumor invades muscularis propria or subserosa; $\mathrm{t} 3$, tumor penetrates the serosa without invasion of adjacent structures; $\mathrm{t} 4$, tumor invades adjacent structures

poorly differentiated adenocarcinoma solid type; por2, poorly differentiated adenocarcinoma non-solid type; sig, signet-ring cell carcinoma; and for depth of invasion, $\mathrm{t} 1$, tumor invades lamina propria or submucosa; $\mathrm{t} 2$, tumor invades muscularis propria or subserosa; $\mathrm{t} 3$, tumor penetrates the serosa without invasion of adjacent structures; $\mathrm{t} 4$, tumor invades adjacent structures. The numbers of infiltrating mast cells increased with tumor depth as follows: $\mathrm{t} 1,41 \pm 4$; $\mathrm{t} 2,81 \pm 14$; $\mathrm{t} 3,104 \pm$ 15 ; and $\mathrm{t} 4,163 \pm 51$. We also analyzed the data according to histologic type; the numbers of mast cells around grstric cancer nests were: tub1, $41 \pm 4$; tub2, $89 \pm 19$; por1, $98 \pm 15$; por2, $101 \pm 16$; and sig, $48 \pm 7$. Mast cells in specimens of patients with metastatic lymph nodes were significantly increased in number $(130 \pm 14)$ in comparison with numbers in specimens from those without metastatic lymph nodes $(43 \pm 3)$. Mast cell numbers in specimens of patients with lymphatic or vessel invasion (128 \pm 14 ) were significantly higher than those in specimens from patients without lymphatic or vessel invasion $(43 \pm 3)$. When we analyzed the data according to the cumulative stage grouping, there was a trend for mast cell numbers to become larger as the histologic stage increased. Among 43 patients with $\mathrm{t} 2$ or 


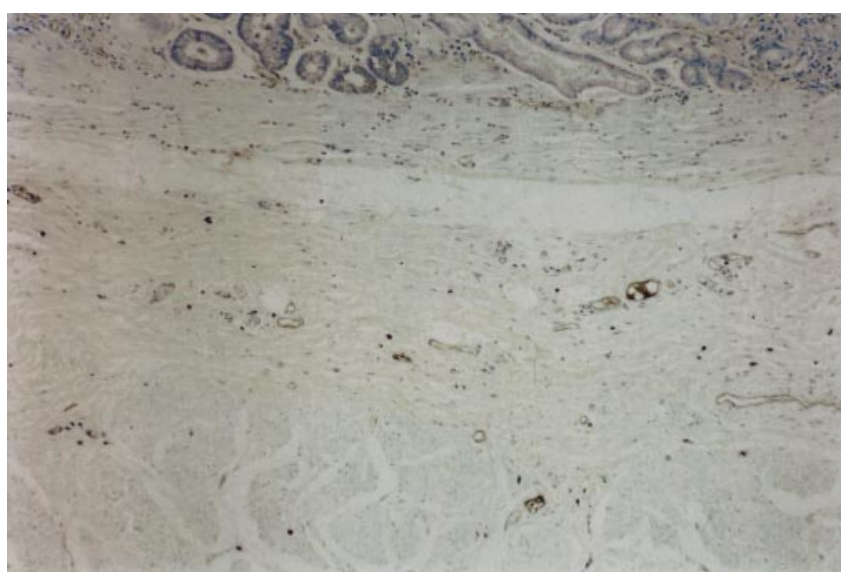

Fig. 1. Mast cells were stained purple and blood vessels were stained brown by double staining with toluidine blue and antifactor VIII polyclonal antibody. In normal gastric tissue, mast cells and blood vessels existed diffusely from the submucosa to the muscle layer; the average mast cell number was $27 \pm 1$ and average blood vessel number was $22 \pm 2$ per high-power $(100 \times)$ field by light microscope. $\times 100$

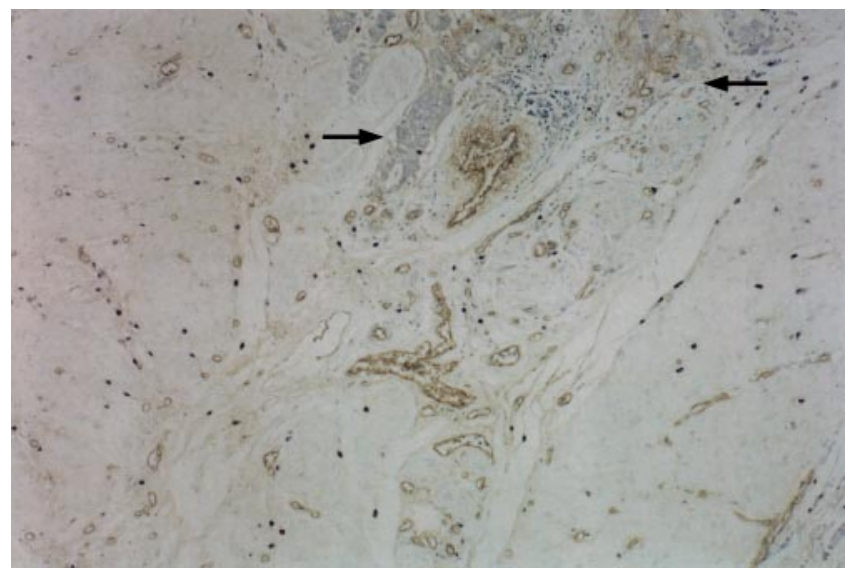

Fig. 2. Mast cells were counted around the tumor edge of gastric cancer nests. Arrows indicate cancer cells on the tumor edge. The average mast cell number in the tumor tissue of 102 patients with gastric cancer $(70 \pm 6)$ was significantly higher than that in normal gastric tissue. The average blood vessel number in the tumor tissue of 49 patients with gastric cancer $(54 \pm 5)$ was significantly higher than that in normal gastric tissue. $\times 100$

t3, 23 lymph-node-positive patients had a significantly higher number of mast cells than 20 lymph-node-negative patients (Fig. 3). Figure 4 shows the correlation between mast cell number and blood vessel number around gastric cancer cells. When the blood vessel numbers were plotted against the mast cell numbers, a significant correlation was found between the numbers of blood vessels and the numbers of mast cells around gastric cancer cells $(r=0.783 ; P<0.0001)$.

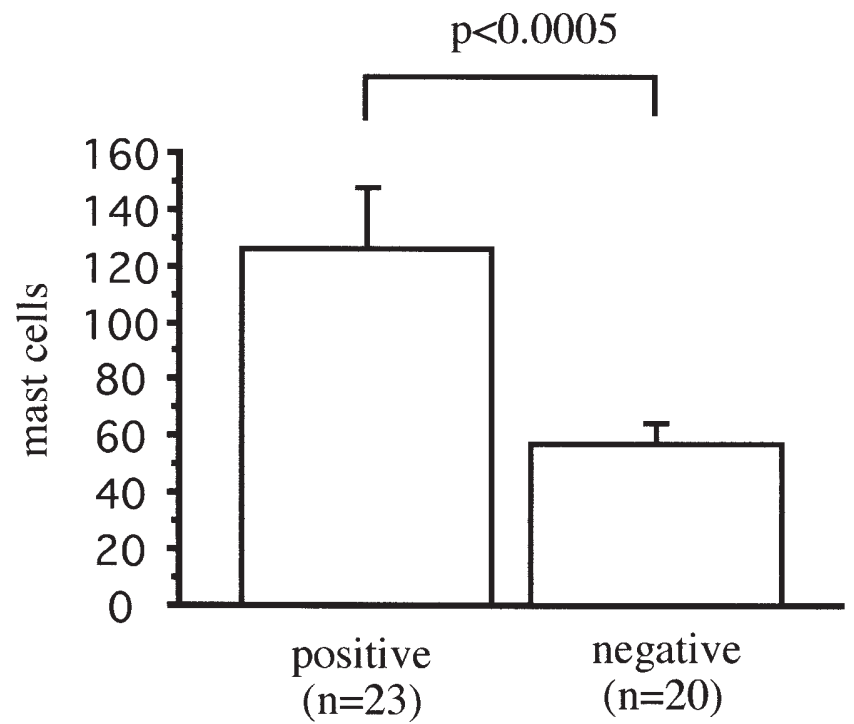

Fig. 3. Relationship between mast cell number and lymph node metastasis in 43 patients with $\mathrm{t} 2$ or $\mathrm{t} 3$. Lymph nodepositive patients $(n=23)$ had a significantly higher number of mast cells than lymph node-negative patients $(n=20)$. (See Table 2 footnote for definitions of $\mathrm{t} 2$ and $\mathrm{t} 3$ )

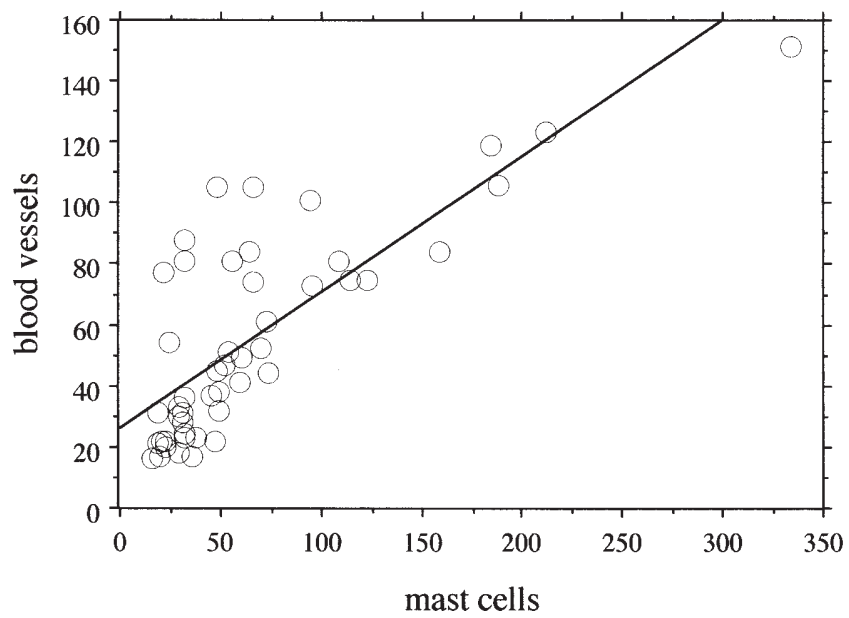

Fig. 4. Scattergram showing the correlation between mast cell and blood vessels around gastric cancer cells for 49 of the tumors studied. When the blood vessel numbers were plotted against the mast cell numbers, a significant correlation was found between blood vessels and mast cells around gastric cancer cells. $\mathrm{Y}=0.438 \mathrm{x}+26.319 ; r=0.783 ; P<0.0001$

\section{Prognosis}

The patients specimens were divided into two groups: those with a low number of mast cells (less than 70 mast cells per visual field $)(n=73)$ and those with an increased number of mast cells (more than 70 mast cells per visual field) $(n=29)$.

The overall survival rate is shown in Fig. 5. The 3-year survival rate was $93.1 \%$ in the group with a low number 

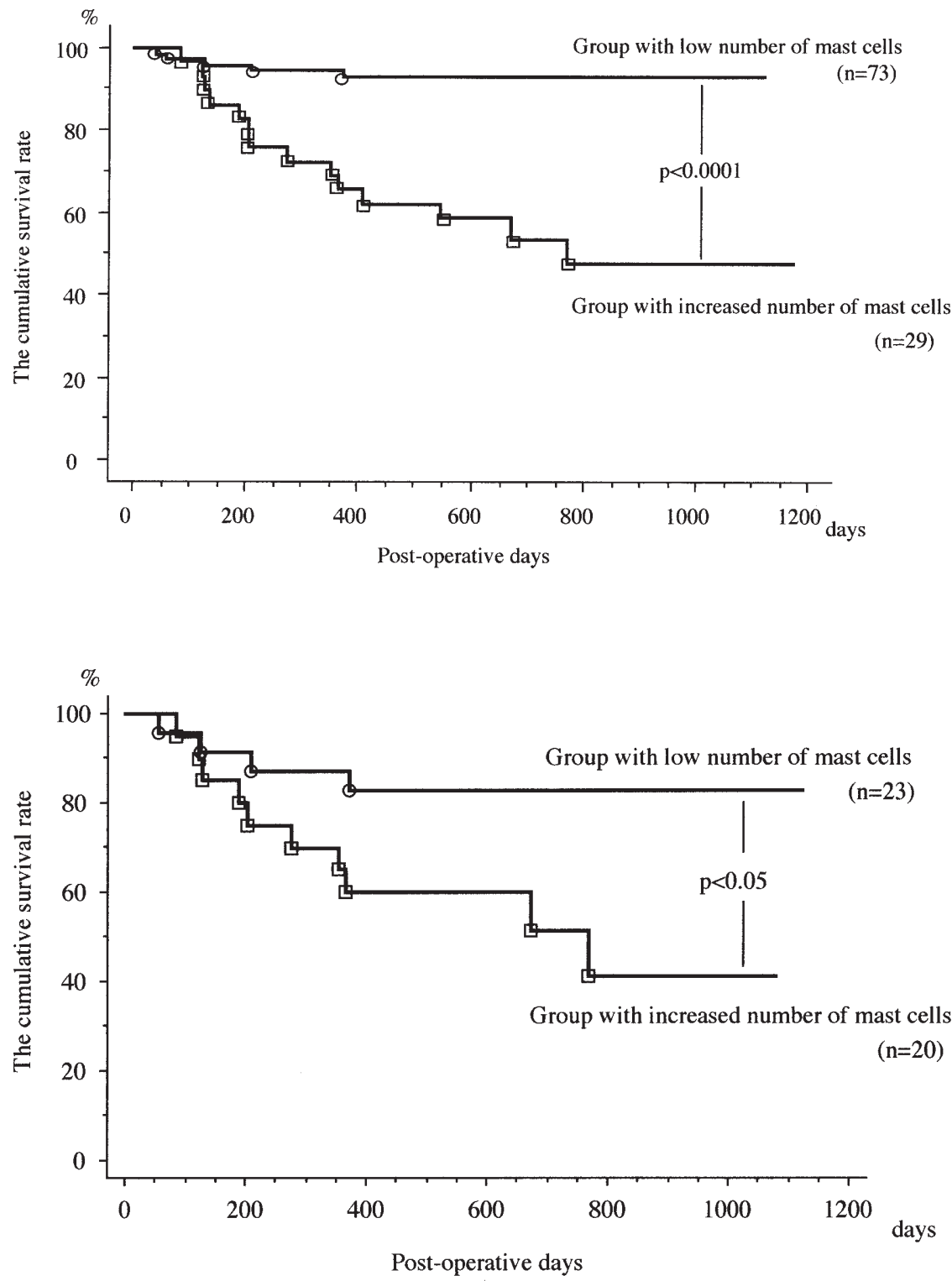

Fig. 5. Overall postoperative survival curves $(n=102)$. The 3 -year survival rate was $93.1 \%$ in the group with a low number of mast cells, and $47.4 \%$ in the group with an increased number of mast cells. There was a significant difference between the two groups $(P<0.0001)$ of mast cells, and $47.4 \%$ in the group with the increased number of mast cells. There was a significant difference between the two groups $(P<0.0001)$. The 3 -year survival rate of the patients with $\mathrm{t} 2$ or $\mathrm{t} 3$ was $82.6 \%$ in the group with a low number of mast cells, and $41.1 \%$ in the group with an increased number of mast cells (Fig. 6). A significant difference was seen between these groups $(P<0.05)$.

\section{Discussion}

Mast cells and blood vessels were clearly two-color stained by double staining of toluidine blue and factor VIII, so they were easily recognized from other cells. We confirmed an increased number of mast cells in histologic sections of gastric cancer. The number of mast cells correlated significantly with the depth of invasion, lymph node metastasis, lymphatic or vessel invasion, and the histologic stage. The number of mast cells also correlated with the number of blood vessels around gastric cancer cells; the correlation coefficient was 0.783 . In the histologic sections, mast cells were localized near the new microvessels; we also found many degranulated mast cells (Fig. 7).

Many tumor-associated mast cells have been found to undergo degranulation and release of granular components such as heparin and histamine [6]. Mast cell granule products, including heparin and histamine, have been shown to potentiate endothelial cell migration [14] and proliferation [15] and to induce adhesion molecule expression on endothelial cells, potentially leading to 


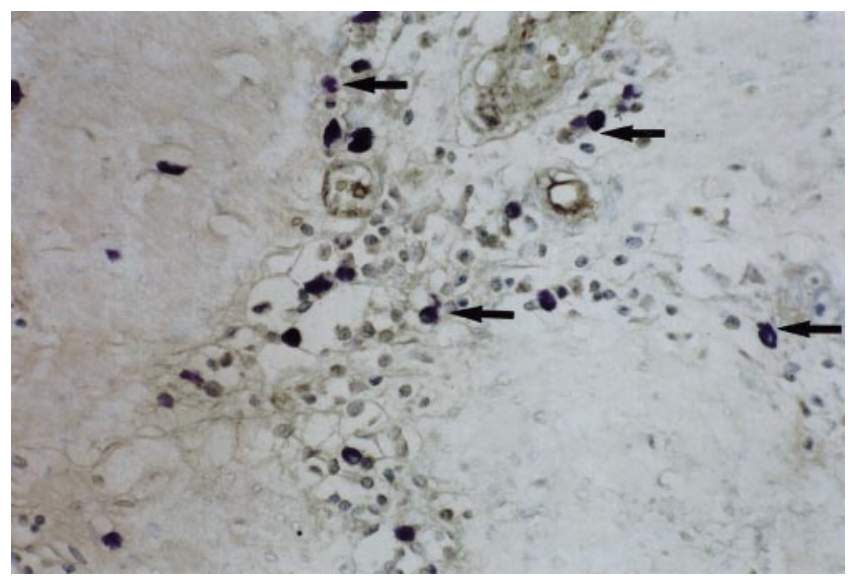

Fig. 7. Mast cells localized near the new vessels around gastric cancer cells. Mast cells were found to undergo degranulation and release of granular components (arrows). $\times 400$

increased tumor angiogenesis and metastasis [16]. Tumors injected into mast-cell deficient mice [17] or into mice treated with inhibitors of mast cell degranulation $[18,19]$ show decreased tumor vascularity, tumor growth, and metastasis, indicating that mast cell granule products enhance tumor growth and metastasis, leading to the suggestion that anti-mast cell agents may be useful in cancer chemotherapy. Endothelial cell migration and proliferation will accelerate tumor angiogenesis around gastric cancer cells. The postoperative survival curve in our series revealed that patients with an increased number of mast cells had a poorer prognosis than patients with a low number of mast cells. All these results suggest that mast cell accumulation at the tumor site may lead to increased rates of tumor vascularization and consequently, increased rates of tumor growth and metastasis.

The accumulation of mast cells in tumors could be due to the active migration of mast cells or mast cell precursors to the tumor site in response to tumorderived chemoattractants. It is now known that both mucosal and connective tissue-type mast cells are motile and respond to the migration activity of a variety of agents including the tripeptide glycylhistidyllysine [20], interleukin-3 [21], stem cell factor [22], and laminin fragment containing the IKVAV domain [23]. The role of these factors in tumor-directed mast cell migration has not been thoroughly investigated and none have been directly implicated in this process. We previously reported the purification of tumor-derived mast cell motility factor from a murine bladder carcinoma cell line that stimulated the migration of cultured marrowderived mast cells in vitro [24]. Further characterization revealed that the mast cell motility factor had the physical and biological properties of the autocrine motility factor [24]. The tumor-derived autocrine motility factor [25] may have a key role in stimulating tumor autocrine motility, as well as the motility of mast cells around gastric cancer cells. Further studies of the correlation between autocrine motility factor and mast cells may be warranted.

\section{References}

1. Baroni C. On the relationship of mast cells to various soft tissue tumors. Br J Cancer 1964;18:686-91.

2. Glowacki J, Mulliken JB. Mast cells in hemangiomas and vascular malformations. Pediatrics 1982;70:48-51.

3. Ho KL. Ultrastructure of cerebellar capillary hemangioblastoma. Acta Neuropathol (Berl) 1984;64:308-18.

4. Aiba M, Iri H, Suzuki H, Kageyama K, Kawai T, Abe O, et al. Numerous mast cells in an 11-deoxycorticosterone-producing adrenocortical tumor. Arch Pathol Lab Med 1985;109:357-60.

5. Cawley EF, Hoch-Ligeti C. Association of tissue mast cells and skin tumors. Arch Dermatol 1961;83:92-6.

6. Flynn EA, Schwartz JL, Shklar J. Sequential mast cell infiltration and degranulation during experimental carcinogenesis. J Cancer Res Clin Oncol 1991;117:115-22.

7. Kessler DA, Langer RS, Pless NA, Folkman J. Mast cells and tumor angiogenesis. Int J Cancer 1976;18:703-9.

8. Weidner N, Semple JP, Welch WR, Folkman J. Tumor angiogenesis and metastasis-correlation in invasive breast carcinoma. New Engl J Med 1991;324:1-8.

9. Maeda M, Chung Y, Takatuka S, Ogawa Y, Sawada T, Yamashita $\mathrm{Y}$, et al. Tumor angiogenesis as a predictor of recurrence in gastric carcinoma. J Clin Oncol 1995;13:477-81.

10. Toi M, Hoshina S, Yamamoto Y, Ishii T, Hayashi K, Tominaga $\mathrm{T}$. Tumor angiogenesis in breast cancer: Significance of vessel density as a prognostic indicator. Jph J Cancer Chemother 1994; 21(Suppl II):178-82.

11. Hartveit F, Thoresen S, Tangen M, Maartmann-Moe H. Mast cell changes and tumour dissemination in human breast carcinoma. Invasion Metastasis 1984;4:146-55.

12. Hsu SM, Raine L, Fanger H. Use of avidin-biotin-peroxidase complex $(\mathrm{ABC})$ in immunoperoxidase techniques: a comparison between $\mathrm{ABC}$ and unlabeled antibody (PAP) procedures. J Histochem Cytochem 1981;29:577-80.

13. Japanese Research Society for Gastric Cancer. The general rules for gastric cancer study. Tokyo: Kanehara 1993.

14. Azizkhan RG, Azizkhan JC, Zetter BR, Folkman J. Mast cell heparin stimulates migration of capillary endothelial cells in vitro. J Exp Med 1980;152:931-44.

15. Marks RM, Rouche WR, Czerniecki M, Penny R, Nelson DS. Mast cell granules cause proliferation of human microvascular endothelial cells. Lab Invest 1986;55:289-93.

16. Klein LM, Lavkar RM, Matis WL, Murphy GF. Degranulation of human mast cells induces an endothelial antigen central to leukocyte adhesion. Proc Natl Acad Sci USA 1989;86:8972-6.

17. Starkey JR, Crowle PK, Taubenberger S. Mast cell-deficient $w / w^{v}$ mice exhibit a decreased rate of tumor angiogenesis. Int J Cancer 1988;42:48-52.

18. Norrby K, Jackobsson A, Sorbo J. Mast-cell secretion and angiogenesis, a quantitative study in rats and mice. Virchows Arch B Cell Biol 1989;57:251-6.

19. Dabbous MK, Haney L, Nicolson GL, Eckley D, Wooley DE. Mast cell modulation of tumour cell proliferation in rat mammary adenocarcinoma 13762NF. Br J Cancer 1991;63:873-8.

20. Poole TJ, Zetter BR. Stimulation of rat peritoneal mast cell migration by tumor-derived peptides. Cancer Res 1983;43:5857-61.

21. Matsuura N, Zetter BR. Stimulation of mast cell chemotaxis by interleukin 3. J Exp Med 1989;170:1421-6. 
22. Meininger CJ, Yano $\mathrm{H}$, Rottapel $\mathrm{R}$, et al. The c-kit receptor ligand functions as a mast cell chemoattractant. Blood 1992;79: 958-63.

23. Thompson HL, Burbelo PD, Yamaha Y, Kleinman HK, Metcalfe DD. Mast cells chemotax to laminin with enhancement after IgEmediated activation. J Immunol 1989;143:4188-92.
24. Yano H, Zetter BR. Purification and characterization of a tumorderived mast cell motility factor that possesses autocrine motility activity (abstract). Mol Biol Cell 1992;3:360.

25. Liotta LJ, Mandler R, Murano G, Katz DA, Gordon RK, Chiang PK, Schiffmann E. Tumor cell autocrine motility factor. Proc Natl Acad Sci USA 1986;83:3302-6. 